\author{
Marcin Lul \\ Wydział Filologiczny \\ Uniwersytet w Białymstoku \\ e-mail: marcinlul@wp.pl
}

\title{
Przybłęda. \\ Swój jako obcy w pismach Józefa Ignacego Kraszewskiego (po roku 1863)
}

obcym i przybłędą zwać się zaczął Polak, który z jednej dzielnicy do drugiej przybywa ${ }^{1}$.

Kraszewski w jednej ze swoich ostatnich powieści współczesnych $\mathrm{Na}$ tułactwie skonstruował obraz międzyzaborowej wędrówki szlachcica polskiego, wydziedziczonego podstępnie przez szwagra z resztek ojcowizny, ziemi położonej $\mathrm{w}$ zaborze rosyjskim. W celu zagarnięcia dóbr należących do Floriana Małdrzyka uknuta została podstępna intryga "polityczna”: pod wpływem fałszywej denuncjacji Florian był podejrzewany przez miejscową władzę o nieprawomyślne postępowanie „z powodu osób, które w tym [jego] domu bywają, rozmów nieoględnych, jakie się tu prowadzą"2. Małdrzyk pod presją okoliczności zgodził się na zawarcie umowy sankcjonującej sprzedaż majątku na rzecz siostry. Miał on wyjechać za granicę, a po urządzeniu się w nowym miejscu pobytu zabrać tam córkę Monikę, która do tego nieokreślonego bliżej czasu razem ze swoją opiekunką panią Lasocką musiała pozostać pod kuratelą nieprzyjaznych jej gospodarzy zagarniętej posesji.

\footnotetext{
${ }^{1}$ J. I. Kraszewski, Program polski 1872. Myśli o zadaniu narodowym zebrane $i$ spisane przez..., Poznań 1872, s. 8.

2 J. I. Kraszewski, Na tułactwie. Obrazy wspótczesne, Kraków 1979, s. 25. W następnych cytatach podaję w nawiasie numery stron. Pierwodruk książki: Warszawa 1882.
} 
Scenariusz wydarzeń zmuszających szlachcica $\mathrm{z}$ Kongresówki do ucieczki za kordon prowokacyjnie uwłacza kanonicznym wersjom rodzinnych historii długiego męczeństwa, powtarzanych chętnie przez autorów piszących "kronikę" narodowej niewoli. Bezpardonowe wykorzystanie koniunktury państwa policyjnego, wroga ojczyzny, w celu osiągnięcia materialnych korzyści, i to za cenę podwójnej krzywdy wyrządzonej członkowi rodziny - taka sytuacja zakrawała na moralny skandal. Postępek szwagra i siostry stanowił de facto dobrowolne wyłączenie się ze wspólnoty wartości opartej na społeczno-patriotycznej misji przypisywanej w XIX wieku każdej rodzinie polskiej. Chrześcijańska tradycja, wzmocniona poczuciem narodowej wspólnoty cierpiących, nakładała na rodzinę obowiązek zachowania domowych (czytaj: ojczystych) cnót; religijna pieczęć wzniosłego posłannictwa nakazywała kultywować prywatne formy polskości, zabronione gdzie indziej, w życiu publicznym.

Tak ponury przekaz współczesny wyszedł spod pióra znanego wszystkim pisarza, który od dwudziestu lat pędził żywot pustelnika zamkniętego w drezdeńskiej samotni, podczas gdy jego powieści, dostępne także w przekładach na inne języki, rozchodziły się nie tylko wśród ziomków pozostających po tamtej stronie kordonu, ale również po całej niemal ówczesnej Europie. W świadomości potocznej kilku pokoleń Polaków utarło się przekonanie o niesłychanej ruchliwości geograficzno-umysłowej Kraszewskiego. Był on na różnych etapach swojego długiego życia gospodarzem - Wołyniakiem, mieszkańcem Wilna, Żytomierza, Warszawy, Drezna, europejskim podróżnikiem-korespondentem, a po trosze także ciekawym świata turystą i wreszcie bezdomnym tułaczem ${ }^{3}$. Nie brak również na kartach jego powieści bohaterów zarażonych podobnym bakcylem mobilności. Zarazem jednak $\mathrm{w}$ tekstach Kraszewskiego zmienna konfiguracja różnych porządków czasoprzestrzennych, w których jakieś ,ja” faktycznie uczestniczy lub które myślowo próbuje ogarnąć, rzutowana jest na układ stałych współrzędnych tworzących swego rodzaju mapę mentalną i historyczno-kulturową dawnej ojczyzny, niepodzielonej jeszcze sztucznymi granicami.

Przedrozbiorowe status quo po roku 1795, a jeszcze bardziej po klęsce epopei napoleońskiej 1812 roku, uruchomiło w zbiorowej świadomości urodzonych w niewoli Polaków trudno uchwytny proces idealizacji dawnej, już realnie nieistniejącej wspólnoty mieszkańców tych ziem, które przed rozbiorami tworzyły heterogeniczną całość powiązaną w retrospektywnej, nostal-

\footnotetext{
3 Zob. B. Mazan, Ahaswerus polski według "Nocy bezsennych" Józefa Ignacego Kraszewskiego, „Pamiętnik Literacki” 2000, z. 2, s. 45-73.
} 
gicznej opowieści rówieśników Kraszewskiego jakimś wspólnym pokrewieństwem, bez mała rodzinnymi więzami. Na tle historycznym widziane są w tej optyce wszelkie różnice regionalne. Jednocześnie w miarę upływu lat, liczonych od momentu przymusowego wydalenia polskiego pisarza $\mathrm{z}$ "kraju”, we współczesnym obrazie społeczeństwa trzech zaborów, modelowanym u Kraszewskiego przez gorzkie doświadczenie przedłużającej się emigracji, przewagę zyskują czynniki wskazujące na dotkliwe pęknięcie dawnego spoiwa ponadregionalnej jedności.

Stara Rzeczpospolita nie była tak jednolitą, tak jednobarwną, jak się nam wydawać może. Za czasów jeszcze przedpodziałowych szlachcic wielkopolski, Mazur, Kujawiak, Sandomierzanin, szlachcic kresowy, różnili się od siebie nie tylko mową, po której poznać się dawali, nie tylko prowincjonalizmami, ale obyczajami, pojęciami, fizjonomią. Wątpię jednak, aby różnice charakterów mogły być kiedy tak wybitne, jak są dzisiaj po stuleciu zmienionych stosunków i działaniu wpływów nowych a rozlicznych. Wspólności niewiele, różnice ogromne, odcienie niezliczone. Spotykamy się, nie czując się tak całkowicie braćmi, jakby się spodziewało, gdy podajemy sobie ręce 4 .

Zacytowany fragment Nocy bezsennych dokumentuje w zamierzeniu autora proces odwrotny w stosunku do wyobrażonej (czytaj także: wymarzonej) Polski jako zintegrowanej wewnętrznie całości, proces, który można nazwać nieuniknionym rozpadem „pierwotnych” więzi łączących mimo oczywistych różnic zewnętrznych Mazura z Kujawiakiem, szlachcica wielkopolskiego z „kresowym”. Istnienie w przeszłości takiej ojczyzny-wspólnoty, wzmocnione przynależnością do jednego państwa, straciło swój kompensacyjny charakter $\mathrm{w}$ zwierciadle domowych i emigracyjnych sporów (Białych z Czerwonymi, konserwatystów z radykałami itd.). Cywilizacyjne przemiany $\mathrm{w}$ drugiej połowie XIX wieku, w różnym stopniu i w niejednakowym tempie przebiegające $\mathrm{w}$ państwach zaborczych, nakładały się na granice geopolityczne, wzmagać mogły poczucie kulturowej obcości w międzyzaborowych kontaktach Polaków. „Podajemy sobie ręce”, ale, jak wynika z rozumowania Kraszewskiego, bez silnego poczucia braterskiej solidarności. Rodaków dzieliły, oprócz słupów granicznych, niewidzialne przepaście, prawie jak po trzęsieniu ziemi. Wprawdzie nazywali siebie "braćmi”, ale ich braterstwo legitymowało się już prawie tylko wspólnym sentymentem dla nieobecnej przeszłości, dla jej, dodajmy, bardzo uproszczonych wizji. Przed rozbiorami różnice regionalne świadczyły o jedności w bogatej różnorodności, natomiast w nocy zaborów, po roku 1863 różnicowanie było zdeterminowane długo-

\footnotetext{
4 J. I. Kraszewski, Noce bezsenne, w: tegoż, Pamiętniki, oprac. W. Danek, Wrocław 1972, s. 403.
} 
trwałym istnieniem podziałów o zupełnie innym charakterze. Granice przebiegały między trzema, niezależnymi od siebie organizmami polityczno-kulturowymi. Kraszewskiemu, podobnie jak wielu innym współczesnym obserwatorom życia społecznego i narodowego, nasuwał się smutny i przygnębiający wniosek: czujemy się obco nawet wśród swoich.

Najnaturalniejszą byłoby rzeczą na starość pomyśleć o powrocie na jakiś zagon ziemi własnej; ale do jednych przystęp jest niemożliwy, do drugich losy tych, którzy w nich osiedli, przenosząc $\mathrm{z}$ innych prowincji, odstręczają. Ziomkowie nie zawsze przyjmują po bratersku, a nazwa "przybłędy" dawała się słyszeć zbyt często, więc i w sercu się odbiła i pozostała w pamięci. Być wygnańcem i czuć się nim - to już lepiej u obcych, bo tym wiele przebaczyć można; ale powrócić na ziemię rodzinną i na niej być wytykanym jako "przybłęda”, w niej czuć się wygnańcem i niemiłym gościem, byłoby nadto boleśnie. Lepiej więc pójść między nie swoich, aby swoim nie mieć nic do wyrzucenia i móc ich kochać z daleka ${ }^{5}$.

Miłość na odległość, spleciona nierozerwalnie z pielęgnowaniem wspomnień domu i rodziny, stała się poniekąd losem Kraszewskiego i herbem wygnania tych, co nie mieli dokąd wracać. Perspektywa nieodwracalnego losu, przeznaczenia, nad którym nie sposób zapanować, bynajmniej nie zawsze i niekoniecznie wynikała z wrogości panoszących się wszędzie obcych gospodarzy. Tutaj odsłaniała się pewna paradoksalna prawidłowość: ten, kto choćby raz wyemigrował z ziemi ojczystej, został na zawsze wydziedziczony z przestrzeni swojego dawnego bytu. Geograficzna tożsamość miejsc utraconych nie mogła już gwarantować żadnej reintegracji z naturalnym środowiskiem dawnego życia, ponieważ tego środowiska, tej wspólnoty, a także konstytuujących ją wartości już nie było. Dzieci ojczyzny-matki, jak wtedy mówiono, zgięły karki pod jarzmem macochy (ściślej: trzech macoch). Powroty do „swoich" kończyły się często destrukcją obrazu opiekuńczej, gościnnej i solidarnej Polski, wzywającej synów do połączenia się z "macierzą" na mocy przyrodzonych praw dziedziczenia ${ }^{6}$. Naród jako demokratyczna "całość" (w rozumieniu czasów insurekcji kościuszkowskiej), a także jako mar-

\footnotetext{
5 Tamże, s. 388.

6 Wymownie w tym kontekście brzmią słowa listu Kraszewskiego do brata Kajetana z 27 XI 1870 r.: „Ty mówisz, że węzły familijne pękają. Prawda, ale, Drogi mój, nie nasza to, wygnańców, wina. My się wstydzim w końcu narzucać Wam, choć kochamy i tęsknimy. [...] Dla utrzymania stosunków, mój Kajetanie, trzeba sobie powiedzieć, żeby pisać koniecznie, żeby się, gdy można, widywać" [J. I. Kraszewski, Listy do rodziny 1863-1886. Część 2: Na emigracji, oprac. S. Burkot. Wrocław 1993, s. 122]. Wcześniej, 4 VIII 1868 r. pisał: „wiele myślałem o swoich, o przeszłości, o rodzinie, którą życie rozprasza i jak ziarna... które, gdy wykiełkują na osobne istoty, już zapominają, że ich jedna wydała łupinka" [tamże, s. 95].
} 
tyrologiczna wspólnota wyobrażona egzystował w górnych rejonach poezji emigracyjnej oraz podążającej $\mathrm{w}$ ślad za nią mitotwórczej ideologii ${ }^{7}$.

Mimo żywej recepcji dzieł wieszcza Adama Mickiewicza w każdym z trzech zaborów, codzienność ich rdzennych mieszkańców wymyka się stopniowo spod władzy literatury scalającej na nowo rozbitą społeczność w jednej wizji zbiorowych cierpień teraźniejszych i przyszłego zmartwychwstania. $Z$ jednej strony dramat kanonizujący męczeństwo Polski (nieśmiertelne "poema”, z którego „wszyscy” się wywodzimy), a z drugiej - realne rozproszenie tych, co zwali siebie braćmi, przymus adaptacji jako życia wszczepionego w inny organizm państwowy i kulturowy - to są dwa światy odległe od siebie i nieprzystawalne jeden do drugiego.

„Przybłęda" to ktoś naznaczony stygmatem człowieka rzuconego zmiennym losom "na pożarcie”. Ofiara losu, ale nie w sensie mesjanistycznym. Taka pogardliwa etykieta brzmi gorzej niż tułacz czy emigrant. Jej bliżej nieokreślonym desygnatem jest zespół cech jednostronnie i kategorycznie degradujących przybysza "znikąd”, któremu odebrano własną tożsamość, ponieważ jego imię Polaka nie daje mu prawa obywatelstwa wśród ziomków. „Przybłęda” to ktoś podejrzany, bez mała „konspirator”, a przynajmniej "sympatyk" konspiracji, skorumpowany tajemniczą i dwuznaczną przeszłością, o której "coś" wiedzą zaborcze władze ${ }^{8}$. Inni patrzą na niego z pełną wyższości obojętnością ludzi tutejszych, którym obcy jest etos tułaczy, a jeszcze bardziej spiskowa, choćby tylko domniemana, działalność. Taki wariant własnego losu - groźbę stania się „przybłędą”, Kraszewski musiał z konieczności odrzucić jako przerażające poniżenie. A z drugiej przecież strony proces o zdradę stanu, który wytoczył mu Bismarck, u schyłku jego życia, postawił wycieńczonego pracą i tajną robotą pisarza pod pręgierzem surowej opinii po obu stronach kordonu, opinii złagodzonej dopiero na wieść o urlopie zdrowotnym obwinionego ${ }^{9}$. Okazało się, że można zejść do roli "przybłędy”, nie ruszając się zbytnio z miejsca.

$7 \mathrm{~W}$ podtrzymywaniu mitotwórstwa romantycznego miał udział również Kraszewski-Bolesławita, autor cyklu powieści z czasów ożywienia nastrojów patriotycznych i styczniowego zrywu. Zob. M. Woźniakiewicz-Dziadosz, Powieściowe strategie ideologa, w: tejże, Kraszewskiego wizje przeszłości i przyszłości, Lublin 1997.

8 Byłby to szczególny przypadek biografii-piętna jako rzekomo skrywanej przez podejrzane indywiduum "prawdziwej” tożsamości, „odkrytej” przez władzę (a dokładniej: donosicieli) i zarejestrowanej w "aktach” czy choćby tylko powielanej w społecznym obiegu (tożsamość sfingowana $\mathrm{w}$ celu wyeliminowania osoby z gry interesów). O biografii w znaczeniu rejestru danych por. E. Goffman, Piętno. Rozważania o zranionej tożsamości, przeł. A. Dzierżyńska, J. Tokarska-Bakir, Gdańsk 2005, s. 100-104.

9 Zob. T. Budrewicz, „Kraszewski wolny!" Prasa polska o urlopie więżnia stanu, w: tegoż, Kraszewski - przy biurku i wśród ludzi, Kraków 2004, s. 264-281. Tu także odwołania do innych prac w przypisach. 
Rzeczywistości zaborowych podziałów nie jest w stanie przesłonić nawet reaktywowane przez Władysława Syrokomlę pielgrzymowanie „po swojszczyźnie". Pielgrzym wyruszał w drogę z wehikułem rodzinnych pamiątek, powiększanym i wzbogacanym podczas wieloetapowej wędrówki przez miejsca historyczne, drogie sercu Polaka ${ }^{10}$. „Przybłęda” , pozbawiony tego bagażu $\mathrm{i}$ „,środka transportu”, został wrzucony w egzystencjalną i historyczną próżnię (nie ma „wczoraj”, jest tylko „dziś”). Nie może liczyć na staropolską gościnność, otwierającą wrota każdemu, częstującą przybysza "chlebem i solą". Miejscowi go nie rozpoznają, bo nie należy już do układu teraźniejszych stosunków i interesów. „Przybłęda” jest zbędnym indywiduum, zabłąkanym i kłopotliwym intruzem zakłócającym normalny rytm tego układu.

Więcej nawet - pojawienie się powieściowego bohatera, Floriana Małdrzyka w Poznańskiem grozi katastrofą, ponieważ może przechylić jeszcze bardziej szalę szykan i prześladowań Polaków w Księstwie, narazić niewinnych na kłopotliwy kontakt z pruskim landratem. Ten niewygodny „element” postrzegany jest przez ziemian jako „radykał”, potencjalny czynnik wywrotowy. "Tacy ludzie nam tu wnoszą liberalizm głupi i bezwyznaniowość" [s. 324]. Jak widać, poczucie obcości wśród swoich wiąże się zazwyczaj ze społeczno-polityczną stereotypizacją. Kraszewski zdaje się sugerować czytelnikowi, że również niemiecka propaganda misji cywilizacyjnej na Wschodzie, której siłą napędową stał się stereotyp zaniedbanego „polskiego gospodarstwa" 11, walnie przyczynia się do rozluźnienia wewnątrznarodowej więzi Polaków, rozdzielonych od stu lat granicami państw zaborczych. Wkroczenie przybysza z innych prowincji na obszar modernizującej się Wielkopolski (a Małdrzyk pochodził z dawnej Kongresówki) daje okazję do okazania mu nieznanego w poprzednim stuleciu rodzaju wyższości: „w Księstwie budził on natychmiast niewiarę, wstręt i zyskiwał imię "przybłędy«, z niemiecką szorstkością i wyrachowaniem odtrącano przychodniów, a takie domy jak Miłosław były oazami na pustyni" [s. 313]. Przypadek Małdrzyka w intencji autora powieści ilustrował zjawisko szersze. Mówiło się podobno wówczas w Poznańskiem o jakiejś inwazji „bosonogich włóczęgów” ze wschodu na zachód, wzajemnie przestrzegano siebie, że "taki a taki emigrant z Królestwa był w Bazarze" [s. 328]. Takie postawienie sprawy przez Kraszewskiego zapewne narażało go $\mathrm{w}$ opinii Wielkopolan na zarzut jednostronnego zideologizowania powieściowego dyskursu. Pisarz wszak przemilczał $\mathrm{w}$ tej

10 L. Kondratowicz (W. Syrokomla), Podróż swojaka po swojszczyźnie. Z rękopisu ogłosił W. Korotyński, Warszawa 1914. Zob. M. Witkowski, Syrokomli wycieczka po swojszczyźnie, w: Literackie przystanki nad Warta, red. Z. Szweykowski, Poznań 1962.

11 Zob. H. Orłowski, Polnische Wirtschaft. Nowoczesny niemiecki dyskurs o Polsce, Olsztyn 1998. 
powieści ważny aspekt samomodernizacji wielkopolskiego społeczeństwa, samomodernizacji wymuszonej $\mathrm{w}$ obronie polskiej racji narodowej przed polityką kulturkampfu ${ }^{12}$. Pisarz przekazywał Polakom z innych dzielnic obraz jakby wtórnie utrwalający "dzielnicowy” stereotyp zniemczonego Poznaniaka, co mogło podkreślać tylko dystans tego drugiego wobec zacofanego Galicjanina. Narrator powieści Na tułactwie stwierdzał:

Nic bowiem mniej do siebie podobnego nie ma, przy zewnętrznej i pozornej podobiźnie oblicza, jak Księstwo pod wpływem niemieckiego wychowania i kultu zgniecione - i prowincje te, w których mniej wychowywano, mniej przecywilizowano i gdzie się jeśli nie zewnętrzne znamiona, to charakteru stare sprężyny lepiej uchowały [s. 313].

W tej dość uproszczonej argumentacji Kraszewskiego zbyt pochopnie postawiony został, jak sądzę, znak równości między germanizacją a modernizacją. Owo „przecywilizowanie” poznańskiej prowincji kojarzyło się Kraszewskiemu z nieodwracalnym procesem zanikania kulturowej odrębności całej dzielnicy (peryferii niemieckiego państwa), która różniła się od centrum (Berlina) jedynie (i aż) stopniem rozwoju cywilizacyjnego. Obcość w taki sposób przezwyciężana nigdy nie mogła stać się szansą wzbogacenia rdzennych tradycji o nowe wartości. Na przeszkodzie stało spiętrzenie rozmaitych stereotypów, w które również Kraszewski, patrzący na wszystko z perspektywy drezdeńskiej samotni, był chcąc nie chcąc jakoś uwikłany ${ }^{13}$. Myślenie kategoriami "swoje - obce”, pozostając na zewnątrz diagnozowanego zjawiska „przecywilizowania”, wykluczało możliwość jakiejkolwiek akulturacji Polaków pod panowaniem niemieckim.

Bohater powieści Na tułactwie, eksmitowany z terytorium państwa przez pruskiego urzędnika (znowu za sprawą fałszywej denucjacji zaniepokojonych rodaków), pozbawiony środków do życia poczuł się zmuszony uciekać

12 Zob. L. Trzeciakowski, Wielkopolski program samomodernizacji - ksztattowanie się nowoczesnego społeczeństwa, w: Samomodernizacja spoteczeństw w XIX w. Irlandczycy, Czesi, Polacy, red. K. Makowski, L. Trzeciakowski, Poznań 1999. W napisanych ponad 10 lat wcześniej Rachunkach pisarz docenił zmysł samopomocy Polaków w zaborze pruskim (zob. K. Sołtys, Wielkopolska $w$ "Rachunkach” J. I. Kraszewskiego, w: Europejskość i rodzimość. Horyzonty twórczości Józefa Ignacego Kraszewskiego, red. W. Ratajczak, T. Sobieraj, Poznań 2006), jednak w osobistych zapiskach więziennych (lata osiemdziesiąte) skupił się już tylko na tryumfach bismarckowskiej polityki antypolskiej.

13 Pisarz piętnował nie tylko Niemców, ale również sprusaczonych Polaków, którzy z kolei, w jego przekonaniu, piętnowali „przybłędów” z innych dzielnic. Piętnowanie stawało się bronią obosieczną. Por. M. Biernat i J. F. Dovidio, Piętno i stereotypy, przeł. M. Szuster, w: Społeczna psychologia piętna, red. T. F. Heatherton, R. E. Kleck, M. R. Hebl, J. G. Hull, Warszawa 2008, s. 95-116. 
do gościnniejszej Galicji. Pierwsze doświadczenia z pobytu w Krakowie, tak różne od przykrości doznanych w Poznaniu, działały kojąco na rany znękanych i wypędzonych skądinąd tułaczy.

Dla przybywających z Europy - wystrojonej, świeżej, rojącej się życiem gorączkowym, stara stolica robić musiała wrażenie odkopanej Pompei, jakiegoś prastarego zabytku, który z żywiołem wieku nie miał żadnego związku. [...] Jakaś śniona, nie widziana nigdy, marzona przeszłość w oczach ich stawała się cudowną rzeczywistością.

To charakterystyczne znamię niemal wszystkich słowiańskich narodowości zaniedbanie, brud, lekceważenie wdzięku - wydało się przybywającym niemal miłym. Czuli się tu w domu. [...] Małdrzykowi też serce biło, bo ta prastara twarz, zdawało mu się, prastarego ducha musiała być wyrazem. Ludzie powinni byli tu podobni być do kamieni, takich serdecznych i świętych [s. 356-357].

Podróż z nowej do starej, słowiańskiej Europy w narracji Kraszewskiego to niemal wkroczenie w inny krąg cywilizacyjny, celowy krok wstecz, mający walor inicjacyjnej przygody-snu. Anachronizm skamieniałej przeszłości działał na przybysza jak usypiający narkotyk po doświadczeniach poznańskiej (i nie tylko) nowoczesności. Znamienne wydaje się owo porównanie Krakowa do starożytnego miasta, które zwiedził Kraszewski w czasie swojego włoskiego wojażu w latach pięćdziesiątych. W Pompei z satysfakcją tropił pisarz ślady domowego życia mieszkańców, przerwanego nagle, a zarazem zakonserwowanego przez żywioł ${ }^{14}$. W Krakowie przed bohaterem powieści otwierają się drzwi polskiej gospody, zapełnionej, jak dawniej, tłumem szlacheckich hreczkosiejów. Narrator powieściowej fikcji utrzymuje jednak pewien dystans w relacjonowaniu przeżyć Małdrzyka. Prowadzi go utartym szlakiem dawnych wieków, a jednocześnie podkreśla fantasmagoryczny prawie klimat towarzyszący tej wyprawie w przeszłość. W końcu prastare mury i budowle to $\mathrm{w}$ dosłownym znaczeniu skamielina, szacowny zabytek, który ożywić może wyobraźnia historyczna, zakodowany w pamięci Polaka zbiorowy sentyment do dawnej stolicy. Ludzie tutejsi, przeniesieni jakby $z$ innej epoki, także wydają się (powinni być) postaciami ze snu.

Ostatecznie galicyjska stolica, ów Kraków sprowincjonalizowany przez Austriaków albo, jak kto woli, osnuta mgłą wspomnień polska Pompeja staje się przytuliskiem dla znękanych Małdrzyków, którzy z zachodniej Europy przez Wielkopolskę trafiali tutaj w poszukiwaniu małej życiowej stabilizacji.

14 Zob. E. Kiślak, Podróż i doświadczenie historii, w: Zdziwienia Kraszewskim, red. M. Zielińska, Wrocław 1990, s. 130; M. Lul, Kraszewski: pamięć i zapomnienie, w: Historia - pamięć - tożsamość w edukacji humanistycznej, t. 2: Literatura i kultura, red. Z. Budrewicz, M. Sienko, Kraków 2013, s. 106-109. 
Uregulowane, nieaktywne egzystowanie pod dozorem Polki, która została żoną Floriana, zaspokajało ograniczone potrzeby rozbitka. Wreszcie znalazł swoją przystań. Donosił przyjacielowi: „Miasto nasze jak mumia spowita i zabalsamowana, które ruchu nie potrzebuje - i we śnie czeka zmartwychpowstania" [s. 390]. Florian Małdrzyk dostroił się do tej ogólnej atmosfery. Senne miasto, ciepła posada w biurze ubezpieczeń i troskliwa żona uwolniły go od męczącego władania sobą.

Kontrastowo na tle polskiej prowincji prezentowała się kosmopolityczna Europa, tętniąca życiem i cywilizacyjnym przyspieszeniem. W Dreźnie, na przykład, na Brüllowskiej Terrasie:

Typy fizjognomij najrozmaitsze, ubiory najdziwaczniejsze ocierały się tu o siebie, języki całej Europy brzmiały równouprawnione, prawie głusząc niemiecki. Sasi, którym to przynosiło dochody, nie chorowali jeszcze na wielkogermańską jedność, którą drogo przypłacili - i nie zabraniali nikomu tak mówić, jak go matka nauczyła; nie przeczuwano jeszcze nawet tych czasów, których my dożyliśmy, gdy na kolejach żelaznych junkry pruskie obcej mowy znosić nie zechcą [s. 50].

Zarówno podróżowanie po Europie, jak i stałe osiedlenie w Dreźnie wzbogaciło widzenie Kraszewskiego o niejedną, cenną perspektywę. Patrzył on z pewną nieskrywaną ironią na swoich rodaków, z którymi stykał się przelotnie na ziemi cudzej. Ich „polskość” ulegała nienaturalnej, a nierzadko wręcz - karykaturalnej metamorfozie, zabarwiając się kolorytem obcego kraju lub dostosowując do ogólnego tonu. Produktem finalnym tych niezbyt skomplikowanych adaptacyjnych procesów był swego rodzaju "kosmopolak" czy raczej osobliwy obyczajowy "mieszaniec” albo konglomerat źle dobranych cech rodzimych i tubylczych. To wszystko, mówiąc w pewnym uproszczeniu, składało się na mentalność XIX-wiecznego turysty, kolekcjonera wrażeń, miłośnika ruin, tudzież amatora towarzyskich spotkań na emigracyjnych salonach.

Wycieczki częste do Włoch, do Francji zbliżały mnie do starych, już tak dziwnie zwłoszonych, sfrancuziałych na wątku polskim, żem był w nieustannej obawie zniemczenia mimowolnego. Ale to strach był próżny: atrakcyjnej siły brakło ${ }^{15}$.

Z twierdzeniem o rozproszeniu polskiego żywiołu poza granicami zaborów w europejskiej wieży Babel - w pozornej tylko sprzeczności stoi zda-

15 J. I. Kraszewski, Noce bezsenne, s. 399. 
nie Kraszewskiego zanotowane prawie ćwierć wieku wcześniej w Kartkach z podróży o tym, że "wszędzie znajdujemy siebie i to, cośmy z rodzinnego kątka wywieźli"16. Zatem nowość podróżowania jest często mirażem wyobraźni, apetytem nowoczesnego turysty, któremu zależy tylko na konsumowaniu tego, co widzi i słyszy wokół siebie. Turysta wmawia sobie egzotyzm odwiedzanych miejsc, a jednocześnie go unieważnia, powołując się na powtarzane w przewodnikach stereotypy opisów i „kanoniczne" omówienia atrakcji turystycznych. Realne i nasze własne jest tylko to, co przechowuje nasza indywidualna pamięć - zdaje się sugerować Kraszewski a więc miejsca, z których wyszliśmy na szeroki gościniec europejski - i z którymi przenośnie - wyruszyliśmy $\mathrm{w}$ dalszą drogę. Zetknięcie $\mathrm{z}$ nowymi rejonami Europy zawsze jest aktem podwójnie wartościującym: po pierwsze dlatego, że porównujemy własne doświadczenia z opisem poprzedników (tak Kraszewski sprawdza i weryfikuje przeczytaną wiedzę), po drugie z racji ciągłego, najczęściej nieuświadamianego odnoszenia aktualnych widoków i spostrzeżeń do zapamiętanego i jakby znieruchomiałego obrazu własnej przeszłości, obrazu, którego nie sposób zostawić zupełnie poza sobą, gdzieś w tyle. Przekraczanie granicy własnego domu w myśleniu Kraszewskiego-podróżnika naznaczone jest poniekąd jakimś "grzechem cudzoziemstwa", marnowania czasu na próżniacze wojaże, co oczywiście wcale nie wyklucza rozlicznych pożytków płynących każdorazowo ze zmiany perspektywy. Tym, co rozgrzesza nas z tej pogoni za nowością, jest właśnie aktywizowanie pamięci opuszczonego domu, możliwe dopiero dzięki doświadczeniu podróży. "Cudzoziemstwo" nęci wielu naszych rodaków swoją powierzchowną atrakcyjnością, ale zawsze osnute jest, jak pisze Kraszewski, „,na wątku polskim".

Spotykani na europejskich szlakach Kraszewskiego Polacy są na tyle już „znaturalizowani” w innym „klimacie”, że ich „sfrancuzienie” czy „zwłoszenie" nie musi być automatycznie, czyli ujemnie kojarzone z wynarodowieniem bądź przenarodowieniem. Tym, powiedzielibyśmy dziś, „europolakom" z dużą łatwością przychodzi prezentować się w różnonarodowych kostiumach, bowiem:

Dzisiaj Europę z końca w koniec przewędrowawszy, nie trafi się na wybitniejszą postać, żadna fizjognomia wyrazistsza nie przejrzy przez skorupę cywilizacji. [...] Dawne czasy i u nas, i wszędzie obfitsze były w oryginały, i nie było jeszcze tej łatwości przebiegania świata, która dziś ściera piętna, ogładza obyczaje, przenosi ludzi, a za nimi jakiś ogólny ton europejski, który w istocie zależy

16 J. I. Kraszewski, Kartki z podróży 1858-1864, t. 1, przypisami i posłowiem opatrzył P. Hertz, Warszawa 1977, s. 9. 
na tym, żeby być podobnym do wszystkich, a jak najmniej do siebie samego. Nawet twarze tracą powoli charakter dawny, wybitniejszy, przywdziewając jakąś maskę tandetną, którą staranne wychowanie nadaje... Wszyscyśmy do siebie podobni, z małymi różnicami ${ }^{17}$.

Wyjęte z powieściowego kontekstu powyższe uwagi Kraszewskiego brzmią znajomo dla ponowoczesnego ucha, które z trudem wychwytuje pojedyncze tony w międzynarodowej orkiestrze zjednoczonej Europy, a znacznie częściej natrafia na uśredniający wszystko ton politycznej poprawności i zrównania pojedynczych różnic do jakiegoś punktu neutralnego. Na oczach Kraszewskiego rodziła się nowa „ogólnoeuropejska” mentalność, wyrażająca się w stylu życia, w normach zachowań towarzyskich, które, być może usprawniają wzajemną komunikację, ale również nieuchronnie ją spłycają.

Kosmopolityczny nalot pokrywał „duszę kulturalną” narodów Europy w czasach względnego pokoju, ale wojna francusko-pruska odkryła drzemiące chwilowo w obu narodach wzajemne antagonizmy. Atmosfera ochronna, którą również Kraszewski jako emigrant krótko oddychał w wielojęzycznym środowisku saksońskiej stolicy, powiązanej w dodatku historycznymi więzami z Polską, okazała się snem-przygrywką przed wielkim przebudzeniem nacjonalistycznego ducha Prus, który pożarł także Saksonię i inne germańskie państewka. Drezno dość szybko utraciło status bezpiecznego azylu dla emigracji polskiej.

Uprawiana przez Kraszewskiego jeszcze w latach czterdziestych komparatystyka międzyzaborowa pod wpływem zmian politycznych między rokiem 1864 a 1871 - różnicujących w większym niż dotychczas stopniu sytuację narodowości polskiej w każdym z trzech zaborów, zwróciła się z poziomu analizy życia intelektualnego (piśmiennictwa) bardziej w stronę publicystycznej oceny postaw rodaków, oceny prognozującej i rozrachunkowej zarazem. Przez kilka lat prowadzone Rachunki wydane zostały w Poznaniu w latach 1867-1870, w symbolicznym gnieździe polskości nad Wartą. O Wielkopolanach pod zaborem pruskim pisał Kraszewski w roku 1868, że sparaliżowani są strachem przed wypowiedzeniem śmielszej myśli, naruszającej zbiorowe tabu, poczucie względnego spokoju. Ta ich ostrożność, drażliwość na słowa prowadzić może - ostrzega autor - do starczej zgrzybiałości i mar-

17 J. I. Kraszewski, Pótdiablę weneckie. Powieść od Adriatyku, Kraków-Wrocław 1985, s. 5. 
twoty. Galicjanie wprawdzie umieją krzyczeć, wszystko dyskutują między sobą i upubliczniają, ale ta papierowa i demagogiczna robota nie przechodzi w żaden zorganizowany czyn stanowczy. Galicja - powiada Kraszewski $\mathrm{w}$ trzecim tomie Rachunków - dopiero budzi się z długiego snu. Z kolei ziemiom polskim pod panowaniem moskiewskim przyznaje autor przodownictwo w umacnianiu ducha narodowego, bowiem spod batoga ciemięzcy tryska żywa krew, a wewnętrzna siła moralna jest wprost proporcjonalna do wielkości barbarzyńskiego ucisku ${ }^{18}$.

$\mathrm{Z}$ tej pobieżnej rekonstrukcji sądów pisarza-emigranta na temat usposobień ogółu w poszczególnych zaborach nie wynika, rzecz jasna, wniosek o zasadniczych antagonizmach dzielących Polaków z różnych prowincji. Tym bardziej, że Kraszewskiemu w pisaniu Rachunków przyświecała idea prawdy, która dotykając boleśnie sumienia, poruszy je ku myśleniu perspektywicznemu, „dla jutra”, w kategoriach ponadzaborowej wspólnoty wartości. Zresztą, w uprawianej przez Kraszewskiego komparatystyce międzyzaborowej (by pozostać przy tym określeniu, z braku lepszego) ważniejsze wydają się nie pola wzajemnych uprzedzeń czy nieporozumień, lecz daleko idące konsekwencje naturalnego wrastania w obcą kulturę, mentalność, uwikłania w skomplikowaną sieć obiektywnych uwarunkowań, tworzących środowisko życia, w każdym zaborze inaczej wpływających na kondycję społeczeństwa polskiego.

Wróćmy do Wielkopolan i do Nocy bezsennych, ponieważ znajduje tu pisarz modelowy przykład zdekomponowania binarnego wizerunku Polaka, który albo służy zaborcy i wypiera się rodzimych wartości, albo stawia niezłomnie opór despotyzmowi, identyfikując się w prosty sposób z niezmiennym jądrem, „wewnętrznym ogniem” polskości.

Znam indywidua, które językiem władają po mistrzowsku, uczucia zachowują obywatelskie, są sobą i pragną pozostać, nie przypuszczając nawet zmiany, a bezwiednie całkiem już duchem obcym przesiąkli. Mówiąc z nimi, czujesz wychowańca tych szkół niemieckich, uniwersytetów i życia powszedniego. Ciągłe ocieranie się o obcych, używanie ich języka, nawyknienie do nałamywania myśli do niego, zrobiło ich Germanami, mówiącymi po polsku. Nie rozumieją i nie czują tego nawet, że myślą i obyczajem są w ciągłej sprzeczności z tradycjami, które szanują. Działo się to i dzieje niepostrzeżenie, bezwiednie. Łatwo przewidzieć koniec, jeśli tak pójdzie dalej ${ }^{19}$.

18 J. I. Kraszewski, Rachunki z roku 1868, Poznań 1869, s. 9 i n.

19 J. I. Kraszewski, Noce bezsenne, s. 403. 
Refleksja Kraszewskiego w Nocach bezsennych sytuowała się wprawdzie na poziomie uogólnienia dotyczącego pewnych tylko „indywiduów”, nie była spojrzeniem panoramicznym na całość społeczeństwa polskiego pod panowaniem pruskim. Przecież jednak, pozostawanie na zewnątrz opisywanego procesu, w roli obserwatora, najpierw w drezdeńskiej samotni, a później w moabickiej twierdzy-więzieniu, bezpośrednie i korespondencyjne kontakty z ludźmi ulegającymi nowej metamorfozie czynił autor pamiętnikowych zapisków czymś w rodzaju obiektywnej rękojmi wypowiadanych sądów. Zmian, dokonujących się $\mathrm{z}$ dnia na dzień, $\mathrm{w}$ dłuższej perspektywie czasu nie wyczuwali dostatecznie, zdaniem Kraszewskiego, ludzie „stamtąd", nawykający stopniowo do warunków społecznego bytu, jak do powietrza, którym oddychali. Autor Nocy bezsennych dowodził dalej, że na powierzchni życia publicznego, wśród tak zwanego obywatelstwa, kodeks patriotycznych zachowań pozostawał nienaruszalnym aksjomatem, wspólnym rytuałem - w imię staropolskiego „Kochajmy się” kończyło się każde towarzyskie zgromadzenie. Jednocześnie strategie praktycznego działania w Poznańskiem stanowiły przejaw myślenia według reguł nabytych w pruskiej szkole życia i gospodarowania. Przy zachowaniu pewnych cech sarmackiego kolorytu i marzycielsko-nostalgicznej retoryki, wywołującej z kart poezji romantycznej ducha dawnej Polski, (niektórzy) wielkopolscy panowie stawali się bardzo pragmatyczni w okolicznościach realnego zagrożenia polityką kulturkampfu ${ }^{20}$.

Zarzucano nieraz Kraszewskiemu, że obraz zmian zachodzących w zaborze pruskim odmalował w przesadnie czarnych barwach. Również dzisiejszy stan wiedzy skłania raczej ku bardziej wyważonej ocenie ówczesnej sytuacji i postaw Polaków pozostających na obrzeżach pruskiej monarchii, a wkrótce niemieckiego państwa. Procesy modernizacyjne zachodzące wewnątrz organizmu państwowego, którego częścią składową było

20 Ciekawe i może zaskakująco znajome dla polskiego odbiorcy są słowa, wypowiedziane później, w czasie pierwszej wojny światowej przez pruskiego polityka o zjednoczonym narodzie niemieckim: „Poprzez pruskość staliśmy się w końcu z narodu trubadurów i wiecznych podróżników narodem pionierów i poszukujących kraju osadników. [...] Istotą pruskości była surowość organizacji. [...] Pruskość była duchem, który w Niemczech zastąpił marzycielstwo wolą, pozory rzeczą i rzeczowością, zaś nas [Niemców] ponownie natchnął misją do czynu" [A. Moeller van den Bruck, Pruski styl, w: Prusy - mity i rzeczywistości, wybór, wstęp i oprac. H.-J. Bömelburg i A. Lawaty, przeł. R. Żytyniec oraz J. Kałążny, Poznań 2016, s. 287, 291]. Oczywiście, nie należy kategorycznie wiązać polskiego autorstwa projektu (samo-) modernizacji z bismarckowskim stylem zarządzania. Autorytet Mickiewiczowskiej poezji nieprzerwanie, jak sądzę, sprawował symboliczną władzę nad narodem, także w kołach poznańskich, chociaż w sferze praktycznych rozwiązań trzeba było „nałamywać myśli” do standardów i pojęć wyrażonych za pomocą obcego kodu językowego i kulturowego. 
Wielkie Księstwo Poznańskie, wymuszały konieczność akulturacji, przejęcia obcych narzędzi i wzorów działania, a wszystkie elementy owego procesu stawały się środkiem do celu, by nie dać się zwyciężyć wrogowi przekonanemu o swojej misji cywilizacyjnej wobec polskiego żywiołu ${ }^{21}$. Trudno więc zgodzić się bez zastrzeżeń z opinią Kraszewskiego o zacnych obywatelach z Wielkopolski, że "są zaślepieni w dobrej wierze”.

Ważniejsza jednak wydaje się niezmienna perspektywa rozrachunkowa, która kazała Kraszewskiemu bez sentymentu i nie bez pewnej słuszności wyrokować na odległość, jakby z lotu ptaka, ponad granicami geopolitycznymi o narastającym zróżnicowaniu mentalnościowym i faktycznym oddalaniu się od siebie ziomków zamkniętych w granicach trzech zaborów. Przy tym uwzględnić należy także skomplikowane związki wzajemnego przyciągania i odpychania na linii: zabory - polskie wychodźstwo, którym Kraszewski poświęcił także sporo uwagi w Rachunkach.

Zaryzykować można tezę, iż zarówno międzyzaborowe kontakty, jak i uwidaczniające się przy tej okazji bariery komunikacyjne, utrudniające wzajemne zrozumienie i porozumienie, dawały w rezultacie obraz napięcia między społeczną mimikrą (swój stawał się podobny do obcego) a uczuciowo artykułowaną ideą jedności ziem etnicznie polskich. Tutaj otwiera się rozległe i dotychczas wyrywkowo tylko rozpoznane pole badań, wykraczające poza ramy historii literatury. Na tym polu użyteczne będą narzędzia analizy transgranicznych relacji albo/i przeciwnie: izolacyjnych strategii zamykania się w obrębie przyswajanych - cudzych paradygmatów, fizycznie ograniczonych przebiegiem granic państwowych.

Wróćmy do perspektywy Kraszewskiego. Stawiane przez niego, może na wyrost, pesymistyczne diagnozy o zniemczeniu Wielkopolan są po części zdeterminowane osobistą sytuacją tułacza, tego, co nigdy nie miał pewności, że dotrze do jakiejś przystani, że uda mu się osiągnąć pewny grunt, w którym zapuści korzenie. Pisarz-emigrant, w rozpatrywaniu własnej biografii wyczulony na trafy nieobliczalnego losu, poszukiwał może w swoich rozrachunkowych próbach punktów orientujących go na mapie zbiorowych transformacji. Ojczyźnie - jako mentalnej wspólnocie ludzi myślących podobnie i wartości regulujących wzajemne kontakty - zabrakło na tej mapie miejsca, a przynajmniej miejsce to nie było już taką oczywistością, jak przed opusz-

21 Zob. prace: Procesy akulturacji/asymilacji na pograniczu polsko-niemieckim w XIX i XX wieku, red. W. Molik i R. Traba, Poznań [1999]; W. Molik, Etos Wielkopolan w historycznym rozwoju i ogladzie społecznym, wstęp do: Etos Wielkopolan. Antologia tekstów o spoteczeństwie Wielkopolski $z$ drugiej połowy XIX i XX wieku, wybrał i oprac. W. Molik, Poznań 2005; W. Molik, Inteligencja polska w Poznańskiem w XIX i początkach XX wieku, Poznań 2009 (rozdz. W kręgu oddziatywania kultury niemieckiej i polskiej). 
czeniem przez Kraszewskiego Warszawy i „swoich” na zawsze w przededniu wybuchu powstania styczniowego. Autor Nocy bezsennych wyznawał:

Spuszczam się na przeznaczenie, gdy zawładnąć nim nie umiałem i nie mogę. Drży mi ręka, zapisując te etapy Ahaswerusowskiej włóczęgi. Z Warszawy w ostatnich dniach stycznia r. 1863 wyjechałem w przekonaniu, że ją opuszczam na parę miesięcy, a pozostałem za granicą lat przeszło dwadzieścia w oczekiwaniu czegoś nieokreślonego - na popasie! ${ }^{22}$

Ciągłe zatrzymywanie się "na popasie" oznaczało wieczną tymczasowość i przygodność indywidualnego losu, któremu w tak nieokreślonym kształcie nie udało się nadać sensu romantycznego pielgrzymowania, ponieważ ciążyło na nim symboliczne piętno przybłędy albo pariasa. Ów obcy innym i samemu sobie drezdeński włóczęga mógł za późnym Mickiewiczem powtórzyć niedokończony dwuwiersz: „Uciec z duszą na liście / i jak motyl szukać / tam domku i gniazdeczka" ${ }^{23}$. Wytoczony Kraszewskiemu proces o współpracę z francuskim wywiadem ostatecznie obciążał biografię Kraszewskiego podejrzanym rejestrem szpiegowskich kontaktów, a to sprawiało, że piętnem stawała się sama biografia sławnego pisarza, poddana rewizjonistycznej próbie na arenie międzynarodowej. Rodzinna, nieprzeznaczona do rozpowszechniania korespondencja pisarza z roku 1884 ujawnia prawdziwe źródło jego dotkliwego bólu i ogołocenia z resztek osobistej godności (człowieka, Polaka, chrześcijanina):

Wszyscy ci ludzie, którzy niegdyś okazywali mi tyle sympatii - niestety! - tak się przerazili, że się skompromitują przez kontakt ze mną, że gromadnie zdezerterowali. To trwa już osiemnasty miesiąc. Nie skarżę się na moich przyjaciół w Warszawie - ujdzie jeszcze, lecz w Prusach; ci, którzy mogliby mi być pomocni i być może uratowaliby mnie lub przynajmniej oszczędziliby mi wielu strat i pomyłek - nie dali znaku życia. Otóż jestem zbyt dumny, by żebrać o cokolwiek. Znajdowano cudowne preteksty, by nic nie robić, by mnie ignorować. To nikczemne i podłe i nie mogę o tym myśleć bez oburzenia. Cudzoziemcy, Niemcy, którzy mieliby więcej powodów, by pozostać obojętnymi, bardzo często okazywali mi pewną sympatię i wspomagali mnie swymi radami. Ci, których uważałem za mych braci, zupełnie mnie opuścili. Z pewnością - nigdy tego nie zapomnę. Nie jestem pamiętliwy - lecz ból, jaki odczuwam, pozostanie w mym sercu na zawsze ${ }^{24}$.

22 J. I. Kraszewski, Noce bezsenne, s. 379.

23 A. Mickiewicz, Wiersze w podobiznach autografów. Część druga: 1830-1855, oprac. Cz. Zgorzelski, Wrocław 1998. W poprzednich edycjach incipit brzmiał: „Uciec z duszą na listek...”.

24 J. I. Kraszewski, Listy do rodziny 1863-1886. Część 2, s. 321. 
Rodzinna Polska przepoczwarzyła się za sprawą magdeburskiego procesu w obojętną macochę. "Swoi”, „bracia” stali się dla Kraszewskiego, naznaczonego piętnem „zdrajcy”, nieludzko obcy. Nieznajomi. W tym stanie społecznej anomii, w poczuciu klęski i cywilnej śmierci pisarz dożył swoich ostatnich dni ${ }^{25}$.

\section{Bibliografia}

Bachórz Józef, O zainteresowaniach Kraszewskiego literatura niemiecką, „Przegląd Humanistyczny" 1988, nr 8/9.

Biernat Monica i Dovidio John F., Piętno i stereotypy, przeł. M. Szuster, w: Społeczna psychologia piętna, red. T. F. Heatherton, R. E. Kleck, M. R. Hebl, J. G. Hull, Warszawa: Państwowe Wydawnictwo Naukowe, 2008, s. 95-116.

Budrewicz Tadeusz, „Kraszewski wolny!" Prasa polska o urlopie więźnia stanu, w: tegoż, Kraszewski - przy biurku i wśród ludzi, Kraków: Wydawnictwo Naukowe Akademii Pedagogicznej, 2004, s. 264-281.

Goffman Erving, Piętno. Rozważania o zranionej tożsamości, przeł. A. Dzierżyńska, J. Tokarska-Bakir, Gdańsk: Gdańskie Wydawnictwo Psychologiczne, 2005.

Józef Ignacy Kraszewski a Niemcy. Publicystyka pisarza w obronie polskiego stanu posiadania pod panowaniem pruskim i niemieckim, wstęp, wybór i oprac. E. Czapiewski, Wrocław 1994.

Kiślak Elżbieta, Podróż i doświadczenie historii, w: Zdziwienia Kraszewskim, red. M. Zielińska, Wrocław: IBL PAN, 1990.

Kondratowicz Ludwik (Syrokomla Władysław), Podróż swojaka po swojszczyźnie. Z rękopisu ogłosił W. Korotyński, Warszawa 1914.

Kraszewski Józef Ignacy, Program polski 1872. Myśli o zadaniu narodowym zebrane i spisane przez..., Poznań: Nakładem Księgarni J. K. Żupańskiego, 1872.

Kraszewski Józef Ignacy, Na tułactwie. Obrazy wspótczesne, Kraków: Wydawnictwo Literackie, 1979.

Kraszewski Józef Ignacy, Noce bezsenne, w: tegoż, Pamiętniki, oprac. W. Danek, Wrocław: Zakład Narodowy im. Ossolińskich, 1972.

Kraszewski Józef Ignacy, Listy do rodziny 1863-1886. Część 2: Na emigracji, oprac. S. Burkot. Wrocław: Zakład Narodowy im. Ossolińskich, 1993.

25 Poza zasięgiem niniejszych rozważań pozostaje wizerunek wroga w pismach Kraszewskiego, udokumentowany i omówiony m.in. w pracach: J. Bachórz, O zainteresowaniach Kraszewskiego literatura niemiecka, „Przegląd Humanistyczny” 1988, nr 8/9; A. Staniszewski, Obraz Niemiec i Niemców w korespondencji prasowej Józefa Ignacego Kraszewskiego, w: Wokót stereotypów Niemców i Polaków, pod red. W. Wrzesińskiego, Wrocław 1993, s. 155-175; Józef Ignacy Kraszezwski a Niemcy. Publicystyka pisarza $w$ obronie polskiego stanu posiadania pod panowaniem pruskim i niemieckim, wstęp, wybór i oprac. E. Czapiewski, Wrocław 1994; W. Ratajczak, Słowiańsko-germańskie pogranicze kulturowe w powieści Józefa Ignacego Kraszewskiego „Pogrobek”, w: Europejskość i rodzimość, s. 363-371. 
Kraszewski Józef Ignacy, Kartki z podróży 1858-1864, t. 1, przypisami i posłowiem opatrzył P. Hertz, Warszawa: Państwowy Instytut Wydawniczy, 1977.

Kraszewski Józef Ignacy, Półdiablę weneckie. Powieść od Adriatyku, Kraków-Wrocław: Wydawnictwo Literackie, 1985.

Kraszewski Józef Ignacy, Rachunki z roku 1868, Poznań: Nakładem Księgarni J. K. Żupańskiego, 1869.

Lul Marcin, Kraszewski: pamięć i zapomnienie, w: Historia - pamięć - tożsamość w edukacji humanistycznej, t. 2: Literatura i kultura, red. Z. Budrewicz, M. Sienko, Kraków: Wydawnictwo Libron, 2013, s. 106-109.

Mazan Bogdan, Ahaswerus polski wedtug "Nocy bezsennych” Józefa Ignacego Kraszewskiego, „Pamiętnik Literacki” 2000, z. 2, s. 45-73.

Mickiewicz Adam, Wiersze w podobiznach autografów. Część druga: 1830-1855, oprac. Cz. Zgorzelski, Wrocław: Zakład Narodowy im. Ossolińskich, 1998.

Moeller van den Bruck Arthur, Pruski styl, w: Prusy - mity i rzeczywistości, wybór, wstęp i oprac. H.-J. Bömelburg i A. Lawaty, przeł. R. Żytyniec oraz J. Kałążny, Poznań: Wydawnictwo Nauka i Innowacje, 2016.

Molik Witold, Etos Wielkopolan w historycznym rozwoju i ogladzie społecznym, wstęp do: Etos Wielkopolan. Antologia tekstów o społeczeństwie Wielkopolski z drugiej połowy XIX $i$ XX wieku, wybrał i oprac. W. Molik, Poznań: Poznańskie Towarzystwo Przyjaciół Nauk, Centrum „Instytut Wielkopolski” UAM, 2005.

Molik Witold, Inteligencja polska w Poznańskiem w XIX i początkach XX wieku, Poznań: Wydawnictwo Poznańskie, 2009.

Orłowski Hubert, Polnische Wirtschaft. Nowoczesny niemiecki dyskurs o Polsce, Olsztyn: Wspólnota Kulturowa Borussia, 1998.

Procesy akulturacji/asymilacji na pograniczu polsko-niemieckim w XIX i XX wieku, red. W. Molik i R. Traba, Poznań: Instytut Historii UAM, 1999.

Ratajczak Wiesław, Słowiańsko-germańskie pogranicze kulturowe w powieści Józefa Ignacego Kraszewskiego "Pogrobek”, w: Europejskość i rodzimość. Horyzonty twórczości Józefa Ignacego Kraszewskiego, red. W. Ratajczak, T. Sobieraj, Poznań: Wydawnictwo Poznańskiego Towarzystwa Przyjaciół Nauk, 2006, s. 363-371.

Sołtys Karolina, Wielkopolska w "Rachunkach" J. I. Kraszewskiego, w: Europejskość i rodzimość. Horyzonty twórczości Józefa Ignacego Kraszewskiego, red. W. Ratajczak, T. Sobieraj, Poznań: Wydawnictwo Poznańskiego Towarzystwa Przyjaciół Nauk, 2006.

Staniszewski Andrzej, Obraz Niemiec i Niemców w korespondencji prasowej Józefa Ignacego Kraszewskiego, w: Wokót stereotypów Niemców i Polaków, red. W. Wrzesinski, Wrocław 1993, s. 155-175.

Trzeciakowski Lech, Wielkopolski program samomodernizacji - kształtowanie się nowoczesnego społeczeństwa, w: Samomodernizacja społeczeństw w XIX w. Irlandczycy, Czesi, Polacy, red. K. Makowski, L. Trzeciakowski, Poznań: Instytut Historii UAM, 1999.

Witkowski Michał, Syrokomli wycieczka po swojszczyźnie, w: Literackie przystanki nad Warta, red. Z. Szweykowski, Poznań: Wydawnictwo Poznańskie, 1962.

Woźniakiewicz-Dziadosz Maria, Powieściowe strategie ideologa, w: tejże, Kraszewskiego wizje przeszłości i przyszłości, Lublin: Wydawnictwo UMCS, 1997. 


\section{Vagrant. \\ Fellow Countryman as the Other in Kraszewski's Writings after 1863 \\ Summary}

In Kraszewski's times the term "vagrant" becomes a stigmatizing label. It denotes the Poles who return to politically-oppressed Poland, only to suffer exclusion by their fellow countrymen, who see them as suspicious revolutionists. The writer demonstrates the intersection of Polish and foreign culture from his own position of loner and emigrant in Dresden while the country faces at the time the imminent prospect of territorial fragmentation. The article attempts to interpret the intricate mechanism of changes in Polish mentality and culture which Kraszewski identified as resulting from territorial partitioning of Poland.

Keywords: national identity, cultural identity, politics of place, partitioned Poland, Józef Ignacy Kraszewski 